\title{
Increasing Cases of Online Non-consensual Posting of Adult male Nude Pictures and Videos in Zambia: Views from rural and urban dwellers
}

\author{
Jordan Tembo ${ }^{1}$, Patricia Mambwe ${ }^{2}$ \\ ${ }^{1}$ Kalindawalo General Hospital, P.O.Box 560008, Petauke, Zambia \\ ${ }^{2}$ Department of Nursing, School of Health Sciences, Rusangu University, Monze, Zambia \\ DOI: https://dx.doi.org/10.47772/IJRISS.2021.5340
}

\begin{abstract}
The internet and other digital communication platforms have almost entirely erased affinity and use of the snail mail. As societies get immersed in the use of these technologies, reality sink in that the internet and other online programmes are in fact a cradle of jaw-dropping non-consensual posting of nude photos and videos calculated to damage victims' reputation before the wider society so that they are eternally killed socially. This negative social behaviour is rapidly gaining ground in Zambia. The problem is even of an emergency in nature. It demands extensive academic inquiry and cure because adult males who in the traditional Zambian culture are regarded as custodians and mentors of social norms and cultural values of the young generation are being exposed through non-consensual dissemination of their nude photos and videos online. Between July, 2020 and February 2021 a series of postings online of private photos and videos of adult males filled the social landscape. The objective of this study was to explore views from 30 rural and urban dwellers on this strange social behaviour. The study used a cross-sectional design with a qualitative approach. It was conducted between January and February, 2021. Using a single-interview- per participant, the study found that urbanites in Zambia were aware of what online intimacy was. The study found that adult males engaged in online intimacy for play and pleasure, or because they were caught up in an unsatisfying, boring and unhappy marriage relationships. The study also found that extortion, black mail, and revenge were the reasons for the dissemination of intimate explicit material of others without their consent.
\end{abstract}

Key words: society, non-consensual, pornography, nudity, intimancy, online

\section{INTRODUCTION}

$\mathrm{T}$ echnological advancement has sparked societies to function at a higher social and economical plane. Electronic communication and the internet have pressed societies to unimaginable social transformation. But the internet has also splashed negative social behaviours across societies. One such deviant behaviour is the posting and disseminating of personal nude images and videos of others without their consent with the intention to cause distress (Sepec 2019:1; Bloom, 2014). The internet and social media platforms afford users to share or disseminate nude pictures and videos of themselves or of consenting or non-consenting others (Budde, 2014). Scholars have defined the behaviour of posting nude images or videos of an adult without consent as 'non-consensual pornography,' 'I mage- Based Abuse,' 'involuntary porn' (Budde, 2014; Franklin, 2014). Nonconsensual pornography is defined as 'sexually explicit images or videos of a person posted online without that person's consent especially as a form of revenge or harassment' (Merriam-Webster online Dictionary, 2016). Scholars trace the behaviour of sharing sexual explicit images and videos in the Hustler Magazine. This was done by Expartners on real women without the concerned women's consent during the 1980s (Goudsmit, 2017 citing TsoulisReay, 2014 and Levendowski, 2014). Statistics in developed countries such as the United States and Australia, Starr and Lavis (2018) quoting the studies by Branch et al., (2017) and Henry et al., (2017) found that one in ten people had an intimate image distributed without their consent. In

Africa, few studies have been conducted to explore this rapidly emerging social problem. The recent study in Nigeria by Richard Abayomi Aborisade (2021) conducted among 27 female participants found that survivors of non-consensual pornography reported considerable social consequences of public shame, ridicule, taunting and harassment. Survivors perceived that perpetrators engaged in this social behaviour to satisfy their sexual gratification, entertainment, masculinity, extortion and exploitation (Aborisade 2021:10).

In Zambia, dissemination of explicit sexual material is a new social phenomenon. Zambia is a conservative society. Conservatism is deeply entrenched in people's life ways. Stefan Andreasson (2014) quoting O'Hara (2011) declare, 'conservatives do not simply reject and resist all forms of social change' (Andreasson 2014:2). One of the severely abhorred social intolerable in Zambia is adult nudity. Matters relating to exposed adult nudity are met with overt societal averse. No Zambian cares whether one's exposed head is shorn or not. But the entire Zambian society stands in aghast if one consenting or non-consenting adult exposes their nudity in-person or virtually by means of technology. A baby can crawl, walk, hop about nude. Immediately an adult figure emerges on the scene, its mother literally flies to dress it lest she is frowned upon or verbally censured. Over adult nudity, the Zambian society takes a hard-line stance. 
Children are severely warned, mwana owoonela akulu obooka menso (A child who sees an adult's nudity loses its sight immediately). Adults are ever on the lookout for a child who develops a styl or a small abscess on the eyelid. This is an unquestionable symbolism of norm violation and social degradation. When a youngster faces adult nudity physically in an unexpected way, the options are to crouch immediately, look away while advancing or turn back at once. A woman who sees a man along her path pressed against a tree urinating is expected to hesitate, look away, wait for him to scatter the terminal urine and deposit his golden stick into his pair of trousers before proceeding on her way.

With technological advancement however, trace cases of leaked nude pictures and videos involving teenagers and college students have loomed online platforms in recent years. The Zambian society to such, reacts with alarm and disgust. Elderly citizens are quick to point at gullible youths for moral declension in the country. Between July 2020 and February, 2021, the Zambian society had a peek into the dismal side of digital activities when three cases of leaked adult male nude pictures and videos were posted online. The disseminations were clearly non-consensual. The victims were of high profile personalities. This stunned the entire country.

But it also alerted rural as well as urban dwellers that 'digital intimacy is now commonplace, particularly in this age of smart phone' (Chisala-Tempelhoff \& Kirya, 2016: 2). Zambia is one of the "first five countries in Africa, and the first in the entire Sub-Saharan Africa after South Africa, to leap at the opportunity to have access to the internet on $22^{\text {nd }}$ November, 1994(Mambwe 2015:204). Since then, digital transformation in Zambia is being propelled by the country's aspiration to be an 'information and knowledge-based society by 2030' (Republic of Zambia, Ministry of National Development and Planning 2006). The Zambia Information Communication and Telecommunication (ZICTA) Information and Cmmunication (ICT)'s survey of 2018 , indicates that $14.3 \%$ of the country access internet. The surge in percentage has been augmented by the rise in the number of smart phone ownership in Zambia from 3\% in 2010 to $13.2 \%$ in 2018 (InfoDev, 2014:12; IBRDWorld Bank, 2020: 43). Internet and all other subsidiary technologies are greatly impacting social life in Zambia. Interaction, if not done through in-person, it is done online through texting, emailing, sharing of photos or videos. Posting of non-consensual nudities is rapidly barrelling online platforms. The objective of this qualitative inquiry was to find out what rural and urban dwellers were feeling and wondering in the light of the trident cases of adult male nude images and videos posted online.

\section{MATERIALS AND METHODS}

Studies aimed at exploring society's views and opinions on the dissemination of adult intimate photos and videos have not yet emerged on Zambia's academic research landscape. This study was more of an exploratory academic expedition as such it utilized a cross-sectional study design with a qualitative descriptive approach. The study was conducted between January to February 2021.

The study used the single-interview-per-participant data collection technique. Creswell (1998) suggested the range of 20-30 respondents to be sufficient for an interview-study. This study used 30 participants to achieve 30 individual interviews. To ensure study credibility and dependability, an admixture of rural and urban dwellers, males and females of varying age ranges between 18years to 65 voluntarily participated in the study to "obtain the broadest range of information and perspectives on the subject of study" (Kuzel, 1992:37). Participants were given a comprehensive explanation on the purpose of the study, consent, and audio recording.

Anonymity and confidentiality were assured as participants' names were not recorded anywhere neither were participants allowed to introduce themselves using their names. Interviews were conducted with an atmosphere of informality so that participants could feel free to share their perspective. Each interview lasted 60minutes. Refreshments were provided at the end of the interview for hydration only. It was so encouraging to note that participants were eager to participate in the study. After explaining the purpose of the study, voluntary participation, consent, and confidentiality, participants' faces beamed with excitement. One middle aged female urbanite said, 'I can't wait. Please start the interview. This study is a good one because it is dealing with behaviour gone wrong in the country.' After data collection, recorded interviews were listened to several times. This was done to ensure interviewees' perspectives were familiar for theme emergence.

\section{RESULTS}

Question: Explain to me what you know about online intimate relationships.

This question was aimed at gaining a deeper insight into what society knew about digital intimacy. Younger ruralites and urbanites gave similar responses which clearly indicated that the rural young and the urban young in the country no longer were separated by a deep chasm of lack of exposure to technology in rural areas. It also demonstrated that rural educated youths had made a tremendous catch up either on the use of communication technology - the smart phone or in accessing current information through other sources. Under the task of explaining what an online romantic relationship was, the theme that emerged was the definition of an online intimate relationship.

\section{Definition of online intimate relationship}

Young urbanites defined online intimate relationship as one characterized by social bonds between two intimate individuals sharing thoughts, feelings, emotions and sex through texting, audio calls, video calls including exchange of nude photos and videos. Young ruralites defined online relationship as a loving relationship through the phone or 
computer where lovers share love messages including very personal photos and videos.

'Kwa ine kukondana kwa online ni ija yakuba ati tubanthu tubili twakondana, twalumana matu but tu lipatali napatali or may be cifukwa ca ma reasons yenangu kukambisana olo ku sharing ma ideas, ma feelings even na sex ni through the internet or social media waziba te? (For me an intimate online relationship involves two individuals hotly in love but because of either distance or other reasons they share their ideas, feelings even sex through the internet or social media, Male urbanite young).

Mune mbvwelako ni cikondi capa foni kapena kompyuta cakuti amene ali mu cikondi otumilana ma meseji ya lavu na cinthako mu mphepo. From what I heard it is a loving relationship through the phone or computer where lovers share love messages including nude photos and videos on internet or social media, Male ruralite young).

Elderly urbanites defined online intimate relationship as giving of heart, soul, time, money including very personal photos and videos to the other person through the internet, social media or other digital platforms. Only one elderly ruralite aged 65 years explained that online intimate relationship was a new way of connecting to the person one loves by means of technological tools. Other rural aged participants reported that they had never heard anything about online intimacy. Their ignorance was based on the fact that many ruralites did not possess a phone and those who had one, only used it for calling as it was too ordinary.

One female elderly urbanite defined an online intimate relationship as: A loving relationship where an individual gives their heart, soul, time including money and nowadays nude photos and videos to the partner as a way to affirm that I am yours and you are mine, (Female urbanite, Elderly).

One male rural respondent defined online intimacy as: Ni njira imozi ya cizungu yo unganisila banthu babili mu cikondi cakuti babili aba suza bapeza okumbatilana mumalo yabeka kapena munfinzi mutenzecitila kale, It is a new western way of connecting two people in love so that the two are not seen cuddling each other in lonely or dark places as it was in the olden times (Male ruralite, Elderly).

When participants were asked to rate the approximate prevalence of online intimate relationships involving male adults in the country, the average percentage from urban respondents was over $90 \%$ while the average approximate percentage from the rural respondents was $20 \%$. The reason given by rural respondents of their low estimation was that the village had negligible educated people who owned and knew how to operate a smart phone. Rural as well as urban respondents reported that only educated males who knew how to operate a smart phone were engaged in an online intimate relationship. One urban respondent approximated in the following terms: Ni ba mbili ba zibambo bamene bali mu online relationship na mukazi kupitilila $90 \%$.
Nabaja bamene tiyopa. Baja bamene tipasa ulemu cifukwa ni olemekezeka mlandu waka poto, olo nchito yamene ba cita na bebve cinagwira. A lot of adult males are involved in intimate relationships exceeding $90 \%$. Even those society respects because of the social status they hold even them are deep into $i$, Female middle aged urbanite).

Mwamene nizibila ine, bamuna bamene bali mu ma online relationships nibambili. Sibabelengeka. Ninthawi ce bambili bazankhala exposed. For me, men involved in online intimate relationships are so many. They are uncountable. It's a matter of time many will be exposed, Female urbanite, young).

Question: What are your views on posting nude pictures and videos online of non-consenting male adults in the country?

For systematic columning, responses were categorized into reasons why adult males opted for online intimacy, why intimate photos and videos of non-consenting male adults were posted online, whether this social behaviour would disappear and social consequences of the victims of nonconsensual pornography. Aged ruralites used proverbs and metaphors to express their views as such their responses were winding than direct. Urban respondents' responses were more similar, direct and penetrating. They cited the desire for funfair, boring marriages, naivety, unhappy marriages and influence from others as reasons influencing male adults to engage in online intimacy. Rural respondents cited moral corruption.

\section{Reasons why older men opted for online intimacy}

\section{Desire for fun}

Respondents citing the desire for fun as reason for male adult online- intimate relationships reported that many a married man led a serious bone-dry life without fun. The work he did and the status he held in society demanded exercise of seriousness and formality. At home he dealt with serious matters bordering on making good their children's education and paying home utilities. Lacking informality, play and pleasure, he became vulnerable to the natural craving for informal activities. Work-related pressure and domesticrelated stress agitated his craving for fun. In his vulnerable state, he consciously or unconsciously, stumbled on a young woman who gripped him and stirred his for play and pleasure.

Men especially married men usually lead a serious dry life with little or no fun at all. So when an opportunity presents itself online with a teenager or someone sweet and younger on the other side raining sweet words and acting crazily they are irresistibly drawn to her for online fun they miss at home and work, female young urbanite).

\section{Boring marriages}

Over boring marriages, respondents reported that many married men dragged their emotional feet in and out of boring marriages. Unmarried female respondents vehemently sounded that men felt tired and bored in their marriage 
relationships. Their wives gained weight and lost their appealing physical shape.

They also slowed down on giving full attention to their husbands, slowed down on bedroom agility. Intimate positions for sex remained the same. No new things. No new sex behaviours. No hotness in bed. Sex life was routine, predictable and excessively boring. In the quest for something novel and thrilling men turned to girlfriends for the desired difference. Due to busy schedules to enable them sustain an in-person relationship; they opted to start an online relationship which could still fulfil their sexual fantasies while remaining anonymous. They found that the internet was a trench in which the tallest could lie low without being spotted in their pursuit for pleasure and play. One unmarried female young urbanite lamented:

A lot of men are in boring marriage relationships. Their wives cease to appeal to them either because of age, shape or lack of innovation in the bedroom. Men feel tired of routine so they are forced to try something new, something different, something that can satisfy their unfulfilled sexual longings, Female young urbanite).

Another single female urbanite explained that:

When a man fails to find fun in his own home he gets bored and turns and looks around but fearing gossips from neighbours, friends or workmates he goes to the internet to hide and enjoy sexual fun with a virtual woman, Female urbanite, married).

\section{Naivety}

Respondents citing naivety reported that men belonging to the generation of the yester years were underlings in the world of technology. They exhibited an appalling naivety about the internet and online intimate relationships. They were so trusting of women. They trusted young females they met online. They easily fell in love. Taking advantage of their naivety, the young online groomers began to groom male adults carefully without raising undue suscipicions. The men quickly learnt that sexual fun included undressing and sharing private photos and videos with women online. Respondents made it clear that when dealing with technology, there was a serious power shift from the older generation to the young generation. When older men attempted to step outside their boundaries of technological understanding, they were groomed for shameful exposure to the outside world when something went wrong in their relationship.

A married female urban respondent said:

Technology has totally failed old men. They should settle for ordinary phones and not smart phones to enable them escape the dark side of the internet. They are so trusting. They trust every girl online without them knowing that they are being groomed for a nasty exposure (Female urbanite married).

Unhappy marriages
One male respondent stated that an unhappy marriage was the reason that drove many men out of their marriages to parade for an online intimate relationship. Marriages characterized by chronic serial misunderstandings, unsettled quarrels, undue suscipicions, and personality incompatibilities, partner competition, male belittling, lack of appreciation for the male even when he was trying hard for the family became a fertile ground for adult men to exit while present; in search of fulfilment from anonymous sources usually the internet. The respondent argued:

Men who feel unhappy in their marriage relationships either because of endless misunderstandings and quarrels, unceasing suscipicions that are unsubstantiated usually sidestep into a relationship to help cure the soul's desire for companionship, Male urbanite, middle aged)

Mwanalume anga thawe nofuna mwanakazi muyake ngati pang'ánda ponkhala congo, manyozo, kusoba ulemu kuli mwanalume nthawi zonse cifukwa nawe mwanakazi wephunzila ndiponso ulandila ndalama monga alume bako. Izi zucitika ngako, A man runs away to look for other women if the home is characterized by disrespect, loudness, insults, male belittling or partner completion because the wife and the man are educated and both earn a salary (Female ruralite, Middle aged)

\section{Influence from others}

Urban respondents reported that men had a natural tendency of wanting to be uniquely different from others, to standout among the rest, to demonstrate advanced knowledge about the social world, to be looked upon as wittiest with regard to technological manipulations. In the quest for recognition among peers, they loved to share stories about their internet discoveries on sexuality. To back up their stories they shared photos and videos of beautiful girls including how to access online 'cam dolls'. Through stories about what one saw, heard or stumbled on the internet or other digital platforms usually sexual in nature; weak minded ones were influenced to explore for themselves.

Bamuna benangu sikuti baviziba. Bacita kuuziwa olo kuonesewa nabanzao kuti kuli bvaso. Baonesana ma foto olo ma vidyo yaba kazi okongola pa internet. Baka yesa apeza kuti nizoona. So ndiye mwe bayambila, other men are influenced by their friends or colleagues to start an online intimate relationship through the stories, images or videos they share or show each other and how to access the women online. When they try it works out (Male urbanite, middle aged).

\section{Moral corruption}

One female from the rural area explained that beside a successful man was a wise woman and beside a corrupt man stood a corrupt woman. A man could not post his 'cinthako' (nudities) if there was no deadlier corrupt woman standing by his side to overthrow him morally. 
One thing is so clear here. When a man succeeds, know that besides him stands a wise woman but when a man exhibits morally corrupt behaviour then a corrupt woman stands by his side, (Female urbanite, Married).

\section{Reasons why intimate photos and videos of non-consenting} male adults were posted online

\section{Extortion}

Respondents reported that clever girls who had learnt how to dig around for liquid gold, used on- line relationships to prey on unsuspecting older males for their money and wealth. Old wealth men affectionately called 'blessers' because they blessed young girls with money, expensive phones, designer shoes and clothes, a new car or a house, were enticed in the name of love and fun to share their own nude images and videos. At that point they got trapped. Using the explicit nudities as a weapon, the victim was at the mercy of the woman. For her personal enrichment, the woman could demand whatever and whenever under the threat that if her victim under was unwilling to fulfill her demands then she would pull the loaded porn trigger for the whole world to watch.

Yong girls love well-to-do men. They call them blessers because they give them money, buy them goodies, expensive phones, clothes and sometimes a car or build them a house. If the blesser has a penguin hand, the girl presses demands and if these are not met she threatens or blows the whistle by posting the man's nudes online. That's it, (Female urbanite, young).

\section{Black mail}

One male urban respondent explained that posting of nudities for adult males on line without consent was purely meant to black mail them and kill their careers and their future. He explained that a man's enemies can only give him a killer punch through his girlfriend. With subtlety, they cornered the girl possessing their enemy's nudities and promised her money. For the love of money, the girl leaked her man's nudities causing the man to crush out of society's favour and the man's enemies won the day.

Ba dani ba munthu anyengelela mukazi no mupasa ndalama zolema bwino kuti a ponye vinthako pa social media olo pa internet kumu paila career olo future muzao, A man's enemies entices the woman and gives her much money to leak their enemy or competitor on social media or the internet (Male urbanite, middle aged).

\section{Revenge}

Participants explained that dissemination of personal nudities of another individual without their consent was done out of anger and the desire for revenge against a partner. Participants reported that this was common among couples where the man was either threatening to break up or had terminated the relationship with the woman against her will. One participant gave an example of a man who had promised to divorce his wife to marry his girlfriend but later changed his mind. The respondent explained that in such instances, the ex-partner out of fiery fury for the disappointment, it was possible to post materials that were explicit intimate in nature to embarrass the ex-partner.

When a man threatens to pull out from a relationship with his girlfriend or disappoint the girlfriend for not divorcing his wife to marry her, the disappointed woman has the potential to embarrass the ex-partner as revenge for the disappointment (Male urbanite, middle aged).

\section{Social consequences on victims}

Both urban and rural dwellers explained that the victim of non-consensual pornography suffered social shaming, social stigma, ridicule, rejection and desertion. Consequently the victim lost social acceptance, social respect, social status, social influence, identity, dignity and self esteem. He was a disgraced figure with lost freedom and liberty to interact with others freely or express himself as it were. Society treated the victim as a perpetual social outcast while his wife filed for divorce or taunted him all the way to the day of his death.

His future, his career and opportunities reached a dead end. His family suffered ridicule and exclusion.

Baka ziba banthu zama pikica na mavideo ya cinthako nishi kwake munthu kwasila. Osoba ulemu cifukwa cosekewa na silu kumozi. Oyenda mobenda cifukwa cosoba ufulu na ayake. Paliye angamumbvwela cifukwa ni munthu-munthu tyala. Akazi nawo omuthaba. When people get to know about the posted nude photos and videos then the person involved is finished forever. The victim suffers shame and rejection. Everyone ridicules him. His friends and neighbours desert him because he has no identity and no status. His marriage ends in shame (Female ruralite, middle aged).

Zikacitika cabe azibiletu munthu kuti wataya ulemu, ziko lamukana mpaka m'manda. Bana na bazukulu ali mubvuto kunenewa no nyozewa. Fyuca yake na zabwino zinangu vasilila pameneapo The moment a nude image or video emerges the victim should know that he has lost all respect and dignity because society has rejected him till death. His children and grandchildren will be stigmatized. His future and other rewarding opportunities are gone (Female Urbanite married, Middle aged).

Uyo wapezeka kuti cinthako cake ziko lonse laciona wazibvula eka, wabvula banja lake na ziko lonse. Afunika kukaniwa no mutaya kunja, whoever's nudes are watched by the entire world has shamed himself, his family including society, he should be rejected and casted out socially (Female ruralite elderly).

\section{Whether the social behavior will disappear}

Respondents reported that social behaviour of posting nude explicities of non-consensual adult individuals was permanent and would not go away in the Zambian society because when one casted nudities of others online, automatically they fuelled 
the appetite for another one to do the same until soon everyone would do it until it ceased to be horrific.

We learn behaviour good or bad from others. When one starts, the other one copies and perpetuates bad behaviour, (Male urbanite, elderly).

The only elderly ruralite active in this study echoed similar sentiments but using a metaphor to express his views.

When you see a pigeon then know that the other pigeon is so, so near. When one posts nude pictures and videos of the partner online then know that soon another one will do the same, Elderly Man, ruralite).

\section{DISCUSSION}

The internet and other online media platforms have made communication faster, easier and instant. Despite the pleasant side of the internet, publication of bombshell porn photos and videos of non-consenting adults online exposes potentially the negative side of the internet. In Zambia, this behaviour is strange. It is even stranger when the victims are adults. In the wake of serial dissemination of nude images and videos online between July 2020 and February, 2021 involving adult males of social standing in the Zambian society, this study set out to explore how the Zambian society was feeling and wondering. The study was qualitative in nature and used interviews for data collection.

The study found that urbanites were well informed about online intimate relationships. They defined online intimate relationships as social bonds between two intimate individuals sharing time, money, thoughts, feelings, emotional soul attachment and sex through texting, audio calls, video calls including exchange of personal nude photos and videos.

This definition comes close to the current authoritative definition by Lomanoswka and Guilton (2016) citing Prager (1995) of 'a dydadic exchange that involves sharing what is personal and private arising from interactions involving 'both verbal and non-verbal communication as well as shared behavioural, physical, emotional and cognitive experience' (Prager, 1995 cited in Lomanoswka and Guilton, 2016:19). This study found that educated men who owned and knew how to use a smart phone were more likely to engage in an online intimate relationship than uneducated men who did not know how to use a smart phone. This finding tallies with the assertion by Heather Underwood and Bruce Findlay (2004) that evidence shows that 'those who become involved in romantic online relationships tend to be male, tertiaryeducated and engaged in professional occupations' (Underwood \& Findlay, 2004:128). This study identified social factors that motivated adult males to plunge in the waters of the internet and other communication technology platforms for online intimacy. The study identified the desire for ungated fun, boring marriages, unhappy marriages and peer pressure as triggering social factors influencing male adults to go online for intimancy.
These findings support the argument by Cooper, (1998) in Underwood \& Findlay (2004) that 'the internet has become a way for men who are isolated, bored, and in unfulfilling relationships to express their sexual selves while remaining anonymous (Cooper, (1998) cited in Underwood \& Findlay 2004:128).

This study found that extortion, naivety of male adults on use of communication technology; black mail and revenge were the reasons for posting of non-consensual nudities of male adults in Zambia. These findings are supported to a greater extent by the evidence collected from a study by Aborisade (2021) in which it was found that perpetrators of nonconsensual dissemination of pornographic materials depicting other individuals did so to extort victims for personal gain, to damage the victim's personality for public disrepute or for relationship retribution (Aborisade 2021:10). The study also found that victims of non-consensual pornography suffered social shaming, social stigma, ridicule, rejection and desertion, loss of respect and dignity. The findings are supported by the evidence from Aboisande's (2021) latest study in which victims complained of having suffered public shame, ridicule, taunting and harassment including isolation. The study also found that perpetration of non-consensual pornography has no limits. The behaviour had potential for continuity. This finding is supported by scholars' assertion that 'modern devices afford abundant opportunities for the perpetration of such wrongs without any participation of the injured party' (Warren \& Brandeis, 1890).

\section{CONCLUSION}

Sharing of nude images and videos depicting other individuals without their consent is an emerging social problem in Zambia. The problem is even of an emergency in nature therefore, it demands extensive academic inquiry and cure because adult males who in the traditional Zambian culture are the custodians of social norms and cultural values for the country, are falling prey to non-consensual dissemination of their utterly confidential photos and videos online.

Table1: Demographic characteristics of participants

\begin{tabular}{|c|c|c|c|c|}
\hline Variables & \multicolumn{2}{|c|}{ Urban Respondents } & \multicolumn{2}{|c|}{ Rural Respondents } \\
\hline \multirow{2}{*}{ Gender } & Male & Female & Male & Female \\
\hline & $7(23.3 \%)$ & $8(26.6 \%)$ & $7(23.3 \%)$ & $8(26.6 \%)$ \\
\hline \multirow{6}{*}{$\begin{array}{l}\text { Age( in } \\
\text { Years) }\end{array}$} & $18-25$ & $3(10 \%)$ & $18-25$ & $3(10 \%)$ \\
\hline & $26-33$ & $3(10 \%)$ & $26-33$ & $4(13.3 \%)$ \\
\hline & $34-41$ & $2(6.6 \%)$ & $34-41$ & $3(10 \%)$ \\
\hline & $42-49$ & $2(6.6 \%)$ & $42-49$ & $1(3.3 \%)$ \\
\hline & $50-58$ & $2(6.6 \%)$ & $50-58$ & $2(6.6 \%)$ \\
\hline & $59-66$ & $3(10 \%)$ & $59-66$ & $2(6.6 \%)$ \\
\hline \multirow{4}{*}{$\begin{array}{l}\text { Marital } \\
\text { status }\end{array}$} & Single & 7 & $\overline{\text { Sing }}$ & 7 \\
\hline & Marriec & 8 & \multicolumn{2}{|c|}{ Married 7} \\
\hline & Divorc & ed 0 & \multicolumn{2}{|c|}{ Divorced 0} \\
\hline & Widow & $\begin{array}{ll}\text { ed } & 0\end{array}$ & \multicolumn{2}{|c|}{ Widowed 1} \\
\hline \multirow{3}{*}{$\begin{array}{l}\text { Education } \\
\text { levels }\end{array}$} & \multicolumn{2}{|c|}{$\begin{array}{l}\text { Senior secondary not } \\
\text { completed } 0\end{array}$} & \multicolumn{2}{|c|}{$\begin{array}{l}\text { Senior secondary not } \\
\text { completed } 10(33.3 \%)\end{array}$} \\
\hline & \multicolumn{2}{|c|}{$\begin{array}{l}\text { Senior secondary } \\
\text { completed } 6(20 \%)\end{array}$} & \multicolumn{2}{|c|}{$\begin{array}{c}\text { Senior secondary completed } \\
5(16.6 \%) \\
\end{array}$} \\
\hline & \multicolumn{2}{|c|}{ College not yet } & \multicolumn{2}{|c|}{ College not yet completed 0} \\
\hline
\end{tabular}




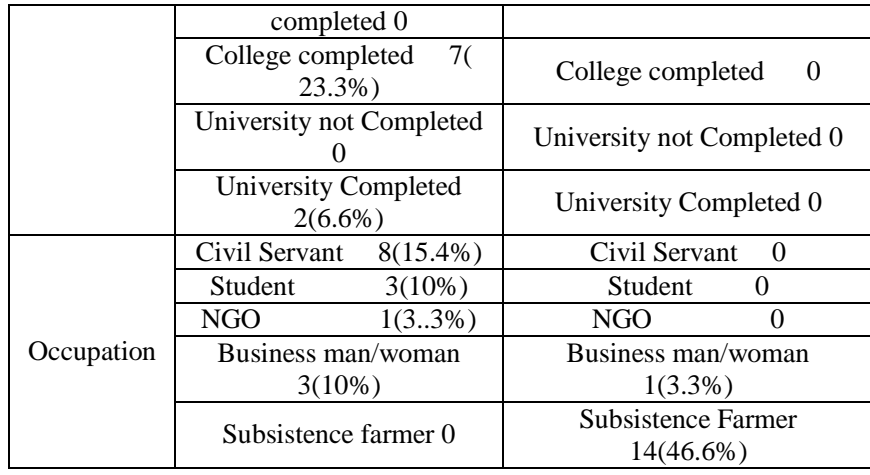

\section{AUTHORS' CONTRIBUTIONS}

JT was responsible for the study conception and design, data collection, and analysis. PM edited the manuscript.

\section{ACKNOWLEDGEMENTS}

The authors are grateful to participants for their willingness to participate in the study.

\section{REFERENCES}

[1] Aborisade, R.A. (2021). Image- Based Sexual Abuse in a Culturally Conservative Nigerian Society: Female Victims' Narratives of Psychosocial Costs. Sexuality Research and Social Policy https://doi.org/10.1007/s13178-021-00536-3

[2] Andreasson, S. (2014). 'Conservatism' in V. Geoghegan and R. Wilford (eds.). Political Ideologies: An Introduction $4^{\text {th }}(e d$.$) .$ London: Routledge in O'Hara, K. (2011). Conservatism. London: Reacreation Books

[3] Bloom, S.(2014). No vengeance for 'revenge porn' victims: Unraveling why this latest female-centric intimate-partner offense is still is still legal, and why we should criminalize it. Fordham Urban Law Journal , 42(1),233-289

[4] Budde, R. (2014). Taking the sting out of revenge porn: using criminal statues to safeguard sexual autonomy in the digital age. Georgetown Journal of Gender and Law

[5] Chisala-Tempelhoff, S., Kirya, M.T. (2016). Gender, law and revenge porn in Sub-Saharan Africa: a review of Malawi and Uganda Palgrave communications DOI: 10.1057/palcomms.2016.69

[6] Creswell, J.W.(1998). Qualitative inquiry and research design: Choosing among five traditions. Thousand Oaks, CA:Sage Publications

[7] Franklin, Z. (2014). Justice for revenge porn victims: Legal theories to overcome claims of civil immunity by operators of revenge porn California Law Justice for Review 102 (5), 13031335

[8] Kuzel, A. (1992), Sampling in qualitative inquiry. In: Crabtree, B. and Miller, W., Eds., Doing Qualitative Research. Newbury Park, Sage

[9] Goudsmit, M. (2017). Revenge pornography : Aconceptual analysis undressing a crime of disclosure in Tsoulis-Reay,
A.(2014). 'A brief History of Revenge porn' New York Magazine, 21 July, 2013. Retrieved from http://nymag.com/news/features/sex/revende-porn-2013-7/,on the $20^{\text {th }}$ of February, 2021 at $20 \mathrm{hrs}$

[10] Lomanowska, A.M. Guitton, M.J. (2016). Online intimacy and well-being in the digital age, internet interventions, vol 4(2), 2016 pg 138-144 ISSN 2214-7829HTTPS://DOI.org/10.1016/j.invent.2016.06.005 (https://www.sciencedirect.com/science/article/pii/s2214829/6300 021 citing K.J. Prager The psychology of intimacy The Guilford Press, New York, NY (1995)

[11] Lovendowski, A. (2014). 'Our best Weapon Against Revenge Porn: Copyright Law? 'The Atlantic 4 February, 2014

[12] Mambwe, E. (2015). The state of internet technology in Zambia. In Media Industry in Zambia: A hand book. Lusaka. DMCS/Mission Press p.p. 203-220

[13] Merriam-Webster online Dictionary, (2016)

[14] Republic of Zambia, Ministry of National Development \& Planning (2006). 'Vision 2030' Government of the Republic of Zambia, Lusaka https://www.mndp.gov.zm/?wpfb.dl=89

[15] Sepec, M. (2019). Revenge Pornography or Non- Consensual Dissemination of Sexually Explicit Material as a Sexual Offence or as a Privacy Violation Offence. International Journal of Cyber Criminology July- December, vol13(2):418-438. DOI:10.5281/zenodo.3707562

[16] Starr, T.S., Lavis, T. (2018). Perceptions of Revenge Pornography and Victim Blame in Branch, K., Hillinski-Rosick, C. M., Johnson, E., \& Solano, G.(2017). Revenge Porn victimization of college students in the United States: An Exploratory analysis. International Journal of Cyber Criminology, 11(1), 128-142. Doi:10.5281/zenodo.495777

[17] Starr, T.S., Lavis, T. (2018). Perceptions of Revenge Pornography and Victim Blame in Henry, N., Powell, A., Flynn, A. (2017). Not just 'revenge pornography': Australians' experiences of imagebased abuse. Retrieved from https://www.rmit.edu.au/content/dam/rmit/documents/college-ofdesign-and-social-context/schools/global-urban-and-socialstudies/revenge_porn_report_2017.pdf

[18] The International Bank for Reconstruction and Development THE WORLD BANK(2020). Accelerating Digital Transformation in Zambia

[19] Underwood, H., Findlay, B. (2004).Internet Relationships and their Impact Relationships. https://www.researchgate.net/publication/228714765 DOI: 10.1375/bech.21.2.127.55422 in Cooper, A. (1998). Sexuality and the Internet: surfing into the new millennium. Cyber Psychology \& Behaviour, 1, 181-187

[20] Warren, S.D., Brandeis, L.D. (1890) The right to privacy. Harvard Law Review, 4, (5) 193-220 doi:10.2307/1321160 December 15, 1890 googlescholar

[21] ZICTA (Zambia Information and Communications Technology Authority). 2018 '2018 National Survey on Access and Usage of Information and Communication Technologies by Households and Individuals: A Demand side Assessment of Access of ICTs in Zambia' ZICTA, Lusaka https://www.zicta.zmDownloads/publications/2018\%20ICT\%20sU RVEY\%20pRELIMINARY \% 20 Report.pdf 